This item was submitted to Loughborough's Research Repository by the author.

Items in Figshare are protected by copyright, with all rights reserved, unless otherwise indicated.

\title{
Reply to Mark Gould and Csaba Szalo
}

\section{PLEASE CITE THE PUBLISHED VERSION}

http://dx.doi.org/10.1177/0038038515597367

\section{PUBLISHER}

Sage Publications / @ The Author

\section{VERSION}

AM (Accepted Manuscript)

\section{PUBLISHER STATEMENT}

This work is made available according to the conditions of the Creative Commons Attribution-NonCommercialNoDerivatives 4.0 International (CC BY-NC-ND 4.0) licence. Full details of this licence are available at: https://creativecommons.org/licenses/by-nc-nd/4.0/

\section{LICENCE}

CC BY-NC-ND 4.0

\section{REPOSITORY RECORD}

Chernilo, Daniel. 2019. "Reply to Mark Gould and Csaba Szalo”. figshare. https://hdl.handle.net/2134/22098. 


\section{Reply to Mark Gould and Csaba Szaló - Daniel Chernilo}

The two commentaries are different in orientation and style. But they share an interest in questions the book raises but does not tackle explicitly: Mark Gould critically outlines the sociology of natural law that may be derived from my reconstruction and Csaba Szaló suggests that my argument on the centrality of universalism is disruptive in relation to contemporary scepticism towards any such claims. As it seeks to account for the natural law foundations of modern social theory, my book then fails to conform to contemporary intellectual sensibilities both inside and outside sociology. I agree and am glad that this is the case. Let me briefly reflect on each commentary.

Gould is right that a strictly sociological account of natural law would have to either tackle the kind of evolutionary narrative he outlines or explain the socio-historical circumstances that have given rise to various natural law doctrines. Gould is again correct that I do not discuss Habermas's evolutionary theory, but it is also true that whilst Habermas's explicit interest in evolutionary theory lasted fifteen years, his engagement with modern natural law is central to his intellectual project as a whole. Indeed, my book's general argument is tributary to Habermas's approach: 'straightforward' natural law arguments have lost a great deal of appeal but the tradition of modern natural law remains, through ideas of freedom, equality and justice, a major normative resource in modernity. Gould also raises two other relevant points. First, he suggests that my use of 'transcendental' in the book has religious connotations but I rather locate it within a Kantian framework that refers to: (1) a generic 'conditions of possibility' argument and (2) a concept of 'selftranscendence' as the human ability to abandon the first person perspective in order to construe normative arguments with a universalistic orientation. Second, I do think that binding moral propositions do follow from natural law. Hans Jonas made this point in his Imperative of Responsibility: suicide in order to avoid immoral acts is available for an individual under extremely hard circumstances, but collective self-annihilation is altogether different because it jeopardizes the very possibility of future human life. A similar claim is found in one of Jonas's best friend, Hannah Arendt, in her argument in favour of the principle of natality.

I concur with Szaló that we ought to reflect on why sociologists have stopped considering philosophical and normative questions as parts of their remit. This is arguably related to our diminishing philosophical training, a salient consequence of which is that we sociologists become so easily impressed by various claims to originality (although we should really know by now that few things are less original than claims to originality). My reconstruction of the relationships between social theory and natural law started as a personal attempt to overcome this 'self-inflicted philosophical ignorance'. I expect it to be difficult to establish the connections between social theory and natural law but it had actually been explicitly made by authors themselves: from Weber to Tönnies, from Leo Strauss to Gillian Rose. And there is the additional question of how to approach normative arguments from a sociological point of view. The by-default position in contemporary sociology is that 
of Bourdieu: the political role of the sociologists lies in helping less powerful actors to mobilise resources in order to achieve their goals vis-à-vis other more powerful ones. But in the book I argue that the normative has to do with the mobilisation of ideas rather than of resources, and ideas become normative if and when they are justified in relation to other ideas or principles that transcend self-centred interest. Normative ideas are articulated, explicitly but quite often also implicitly, through references to the shared properties of our humanity. Sociologists are now quick to follow 'original' arguments about the post- and trans-human - but this is taking place without us having fully understood what we mean by 'the human' in our sociological theories and methodologies. And like it or not, the natural law tradition has been a main repository of such conceptions of the human.

Finally, I should like to thank to Frank Welz (Innsbruck), from the organising committee of the ESA meeting in Torino, for having organised this session on my book. 